\begin{tabular}{|c|c|c|c|c|}
\hline \multirow[t]{3}{*}{ Condition } & \multicolumn{4}{|c|}{ Number of cases notified } \\
\hline & \multicolumn{2}{|c|}{ Period } & \multicolumn{2}{|c|}{ Cumulative } \\
\hline & $\begin{array}{c}\text { March } \\
1991\end{array}$ & $\begin{array}{c}\text { March } \\
1992\end{array}$ & $\begin{array}{c}\text { March } \\
1991\end{array}$ & $\begin{array}{c}\text { March } \\
1992\end{array}$ \\
\hline Adverse reaction & N/A & 2 & N/A & 10 \\
\hline AIDS & *40 & *9 & *63 & *24 \\
\hline Arboviral infection & 152 & 15 & 317 & 61 \\
\hline Brucellosis & 1 & - & 1 & - \\
\hline Cholera & - & - & - & - \\
\hline Diphtheria & - & - & - & 1 \\
\hline Foodborne illness (NOS) & 251 & 12 & 921 & 78 \\
\hline Gastroenteritis (instit) & 16 & 1 & 23 & 92 \\
\hline Gonorrhoea & 44 & 4 & 122 & 49 \\
\hline $\mathrm{H}$ influenzae epiglottitis & 1 & 2 & 2 & 7 \\
\hline $\mathrm{H}$ influenzae $\mathrm{B}-$ meningitis & 4 & 5 & 4 & 19 \\
\hline $\mathrm{H}$ influenzae B - septicaemia & - & 1 & 1 & 2 \\
\hline$H$ influenzae infection (NOS) & 10 & 1 & 19 & 6 \\
\hline Hepatitis A - acute viral & 39 & 28 & 68 & 227 \\
\hline Hepatitis B - acute viral & 1 & - & 5 & 20 \\
\hline Hepatitis B - chronic/carrier & - & 4 & - & 39 \\
\hline Hepatitis B - unspecified & 81 & 23 & 251 & 326 \\
\hline Hepatitis C - acute viral & - & - & 2 & 46 \\
\hline Hepatitis C - unspecified & 33 & 56 & 66 & 432 \\
\hline Hepatitis D & N/A & - & N/A & 1 \\
\hline Hepatitis, acute viral (NOS) & 45 & & 69 & 4 \\
\hline HIV infection & *82 & *77 & *158 & *167 \\
\hline Hydatid disease & - & 2 & 1 & 4 \\
\hline Legionnaires' disease & 7 & 1 & 14 & 9 \\
\hline Leprosy & & - & - & 1 \\
\hline Leptospirosis & 5 & - & 18 & 4 \\
\hline Listeriosis & & - & 3 & 2 \\
\hline Malaria & 4 & 3 & 13 & 20 \\
\hline Measles & 71 & 7 & 113 & 84 \\
\hline Meningococcal meningitis & 1 & - & 5 & 1 \\
\hline Meningococcal septicaemia & 1 & - & 5 & 2 \\
\hline $\begin{array}{l}\text { Meningococcal infection } \\
\text { (NOS) }\end{array}$ & 5 & - & 6 & 4 \\
\hline Mumps & N/A & - & N/A & 4 \\
\hline Mycobacterial tuberculosis & 21 & 5 & 55 & 53 \\
\hline Mycobacterial - atypical & 11 & 1 & 18 & 14 \\
\hline Mycobacterial infection (NOS) & 11 & 3 & 40 & 15 \\
\hline Pertussis & - & & 20 & 13 \\
\hline Plague & - & - & - & - \\
\hline Poliomyelitis & - & - & - & - \\
\hline$Q$ fever & 41 & 5 & 64 & 27 \\
\hline Rubella & 1 & 1 & 4 & 12 \\
\hline Salmonella infection (NOS) & 164 & 13 & 477 & 185 \\
\hline Syphilis & 53 & 9 & 140 & 114 \\
\hline Tetanus & & - & 1 & \\
\hline Typhoid \& paratyphoid & 12 & - & 28 & 8 \\
\hline Typhus & - & - & - & - \\
\hline Viral haemorrhagic fevers & - & - & - & - \\
\hline Yellow fever & - & - & - & - \\
\hline
\end{tabular}

*Data to February only

\section{PuBLIC HEALTH ABSTRACTS}

D rofessor James S. Lawson, Professor and Head of the School of Health Services Management at the University of NSW, has prepared the following public health items from the literature.

\section{ANAL AND CERVICAL CANCER PROBABLY HAVE SIMILAR CAUSES}

Anal cancer is rare, but is more frequent in women than in men. An increase in anal cancer has been suspected in the past two decades, especially among homosexual men. It seems likely that an infectious agent similar to that for cancer of the uterine cervix is involved. In a very large study involving nearly 30,000 women in Denmark, it has been demonstrated that patients with anal cancer were significantly more likely to have had a previous cervical cancer than other patients with cancer.

Melbye M and Sprogel P. Aetiological parallel between anal cancer and cervical cancer, Lancet 1991; 338:657-659.

\section{LIVE LUNG TRANSPLANTATION - DIFFICULT ETHICS}

Lung transplantation (lobe only with respect to live donors) has become a viable treatment option for many patients with terminal pulmonary disease, but the scarcity of donor lungs is a severe constraint. The main risk to the live donor is the risk of lobectomy which carries a mortality rate of less than 1 per cent. The main benefit to the donors is psychological in knowing they have saved the life of another. The ethics are difficult and require careful consultation with donors and recipients on several occasions before the decisions are made.

Shaw LR, Miller JD, Slutsky AS, Maurer JR et al. Ethics of lung transplantation with live donors, Lancet 1991; 338:678-681.

\section{ALCOHOL AND CARDIOVASCULAR DISEASE}

Evidence suggests that two alcoholic drinks a day are associated with no cardiovascular harm and may be protective against coronary heart disease. However, a public health recommendation that emphasised the positive effects of alcohol would be likely to do more harm than good because above two drinks a day, there is evidence of harm biological as well as social. Any increase in overall consumption of alcohol, even as low as an extra one drink a week, has been found in many countries to be associated with a 10 per cent increase in the prevalence of heavy drinkers. Therefore any recommendations in favour of encouraging the public to drink in order to prevent coronary heart disease may well have an adverse effect.

Marmot $M$ and Brunner $\mathrm{E}$. Alcohol and cardiovascular disease: the status of the U-shaped curve, Br Med J 1991; 303:565-568.

\section{ANTIBIOTICS REMAIN VALUABLE FOR MIDDLE EAR INFECTIONS}

Acute painful red ear is a problem commonly encountered in general practice and the dilemma of whether and how to treat this condition remains the subject of continuing debate. However, the published evidence is conflicting. A British study using double blind control techniques has shown that the use of antibiotics (the penicillins), improves short-term outcomes substantially and therefore continues to be an appropriate management policy.

Burke P, Bain J, Robinson D and Dunleavey J. Acute red ear in children: controlled trial of non-antibiotic treatment in general practice, $\mathrm{Br} M \mathrm{Med}$ $1991 ; 303: 558-562$. 